\title{
Work Life Balance of Female Employees in Private Institutions, Gwalior: An Investigation
}

\author{
Mansi Tiwari \\ Assistant professor, Amity Business School, Amity University Madhya Pradesh, Gwalior, 474005
}

\begin{abstract}
Employees are key asset of the organization \& it becomes more obligatory for the employers when it comes to female employees. Female employees are playing dual role, one at the workplace and another at their home. It is difficult for them to manage both the side. Researcher investigated about how the lives of female employees are getting affected due to improper balances in their professional \& personal life. This paper also reveals about what is more obstructing, family obstructs work or work obstructs family and how these imbalances are creating problems like stress, intention to leave, burnout on the part of female employees. This study also recommends what else could be done to improve the work life balances in the life of female employees especially.
\end{abstract}

Key Words: Work Life Balances, Female employees, stress

\section{Introduction}

Work \& life both are the important aspect for any of the organization to manage. This is kind of a situation where as an employee one needs to balance the status between personal \& professional lives. They need to understand how much \& how long they require to work hard so that at the end it is going to be win- win situation for a employee in context of satisfaction from work \& professional life both.

Females are the most delicate employee for any of the organization as they were always being discriminated in our society but some they are trying to mange to deal with such discriminations successfully. As our tradition is concern female is always to be more responsive towards their family responsibilities but now as they are also more active professional world so they are equally responsive towards their work also.

Sometimes, it becomes when it comes to married female employees to face the hardships of professional world where they have to be $100 \%$ effective at work place as competition is very high. But, does this race of becoming expertise in their profession is making female employees more compromising for their employer over their families or creating dilemma what to choose or priority either work or family.

We can see there is a growth in participation of female employees in professional fields making us to realize about their potential to handle simultaneously family \& work life. But, the present scenario employees are working so hard as compared to earlier times \& it results in difficulty to achieve desired work life balances. Effective balance for working women becomes difficult as they marry some additional responsibility takes place $\&$ they become bigger as female become mother which makes them in under pressure to continue with their career. Working females are balancing with all the problems at home as well as at work. They are managing effectively the following components -

1. Self Management

2. Time Management

3. Stress Management

4. Technological management \&

5. Change Management

\section{Methodology}

Both primary \& secondary data is used by researcher. The data is collected by semi-structured questionnaire by surveying 150 females working in private organization. For this study different type private firms have been taken because females work under pressure there. The following table 1 shows the description about the demographic of sample.

\begin{tabular}{|l|l|}
\hline Demographic (Age) & No. of Respondents \\
\hline 20 or Below & 15 \\
\hline $21-30$ & 45 \\
\hline $31-45$ & 30 \\
\hline $46 \&$ above & 60 \\
\hline Total & 150 \\
\hline Organization Type & No of Respondents \\
\hline Academic & 45 \\
\hline
\end{tabular}


Work Life Balance of Female Employees in Private Institutions, Gwalior: An Investigation

\begin{tabular}{|l|l|}
\hline Health Care & 38 \\
\hline Marketing & 32 \\
\hline Insurance & 35 \\
\hline Total & 150 \\
\hline No. of Children & No. of Respondents \\
\hline One & 46 \\
\hline Two & 47 \\
\hline Three or More & 21 \\
\hline None & 36 \\
\hline Total & 150 \\
\hline
\end{tabular}

Table 2:- Statements \& opinions

\begin{tabular}{|l|l|l|l|l|l|l|}
\hline Statements & $\begin{array}{l}\text { Strongly } \\
\text { Disagree }\end{array}$ & Disagree & $\begin{array}{l}\text { Some } \\
\text { what } \\
\text { Agree }\end{array}$ & Agree & $\begin{array}{l}\text { Strongly } \\
\text { Agree }\end{array}$ & $\begin{array}{l}\text { Total } \\
\text { Percentage } \\
\text { \& } \\
\text { Frequency }\end{array}$ \\
\hline $\begin{array}{l}\text { My work \& my home obstruct } \\
\text { each other }\end{array}$ & $\begin{array}{l}6 \\
(4.11 \%)\end{array}$ & $\begin{array}{l}4 \\
(2.66 \%)\end{array}$ & $\begin{array}{l}21 \\
(14 \%)\end{array}$ & $\begin{array}{l}91 \\
(60.66 \%)\end{array}$ & $\begin{array}{l}28 \\
(18.66 \%)\end{array}$ & $\begin{array}{l}150 \\
(100 \%)\end{array}$ \\
\hline $\begin{array}{l}\text { I am able to handle the needs of } \\
\text { my family \& my work both }\end{array}$ & $\begin{array}{l}53 \\
(28.10 \%)\end{array}$ & $(35.33 \%)$ & $\begin{array}{l}30 \\
(20 \%)\end{array}$ & $\begin{array}{l}15 \\
(10 \%)\end{array}$ & $\begin{array}{l}10 \\
(6.66 \%)\end{array}$ & $\begin{array}{l}150 \\
(100 \%)\end{array}$ \\
\hline $\begin{array}{l}\text { I less enjoy my work due to } \\
\text { imbalances in my work - life }\end{array}$ & $\begin{array}{l}10 \\
(6.66 \%)\end{array}$ & $\begin{array}{l}16 \\
(10.66 \%)\end{array}$ & $\begin{array}{l}73 \\
(14.10 \%)\end{array}$ & $(48.66 \%)$ & $\begin{array}{l}30 \\
(20 \%)\end{array}$ & $\begin{array}{l}150 \\
(100 \%)\end{array}$ \\
\hline $\begin{array}{l}\text { I can quit my job if another } \\
\text { balanced job I'll get }\end{array}$ & $\begin{array}{l}18 \\
(12.10 \%)\end{array}$ & $\begin{array}{l}28 \\
(18.66)\end{array}$ & $\begin{array}{l}50 \\
(33.33 \%)\end{array}$ & $\begin{array}{l}49 \\
(32.66 \%)\end{array}$ \\
\hline
\end{tabular}

\section{Result And Discussions}

To find out the exact status of work life balance of female employees of private organization the interpretation of opinion has been appended below-

- In table 2, we can the response towards the statement "My work \& my home obstruct each other" only 4.11 $\%$ ( strongly disagreement) $+2.66 \%$ (disagree) of respondents showed their total disagreement about $6.77 \%$ which means that there work \& their family do not obstruct each other. Whereas $14 \%$ (Somewhat Agree) + $60.66 \%$ (Agree) $+18.66 \%$ (Agree Strongly) which means total $93.32 \%$ of females believes that their work \& family obstructs each other. This indicates that this work life \& simultaneously family life is creating many problems in the life of female employees.

- As regard to the statement, "I am able to handle the needs of my family \& my work both" $28.10 \%$ (Strongly Disagree) +35.33 (Disagree) showed around total $63.43 \%$. Whereas 20\% (somewhat agree) $+10 \%$ (Agree) $+6.66 \%$ (strongly agree) shows total agreement $36.66 \%$ to it. It shows that many females are facing in handling their work \& family needs where as those are able to do so might be because of their profession in which they are working.

- The statement "I less enjoy my work due to imbalances in my work - life" shows that $6.66 \%$ (strongly disagree) $+10.66 \%$ (disagree) which indicate around $17.32 \%$ of female employees are enjoying their job against rest of those who $14.10 \%$ (somewhat agree) $+48.66 \%$ (Agree) $+20 \%$ (strongly agree) total $82.76 \%$ working females are not enjoying their work. It reveals that the major section of working females in private jobs is not happy whereas very few females are enjoying their work that again may be because of their easy nature of job.

- One more statement is there, "I can quit my job if another balanced job I'll get", is revealing the fact that major percentage of female employees in private firms would like to change their job if they will get another balanced opportunity. The study shows $18.66 \%$ (somewhat agree) $+33.33 \%$ (Agree) $+32.66 \%$ (strongly agree) in total $84.65 \%$ of female will change their jobs. Only few would like to be with the same employer as again it depends on the nature of work or other factors to it. The total disagreed female's percentage is $15.43 \%$.

Table -3

\begin{tabular}{|c|c|c|c|c|c|c|}
\hline \multicolumn{7}{|c|}{ Effects of family Obstructions on Work } \\
\hline Statements & $\begin{array}{l}\text { Strongly } \\
\text { Disagree }\end{array}$ & Disagree & $\begin{array}{l}\text { Some what } \\
\text { agree }\end{array}$ & Agree & Strongly Agree & $\begin{array}{l}\text { Total percentage \& } \\
\text { frequency }\end{array}$ \\
\hline $\begin{array}{l}\text { In doing my job my family life got } \\
\text { more interrupted }\end{array}$ & $\begin{array}{l}11 \\
(7.33 \%)\end{array}$ & $\begin{array}{ll}10 \\
(6.66 \%)\end{array}$ & $\begin{array}{l}19 \\
(12.66 \%)\end{array}$ & $\begin{array}{l}60 \\
(40.02 \%)\end{array}$ & $\begin{array}{l}50 \\
(33.33 \%)\end{array}$ & $\begin{array}{l}150 \\
(100 \%)\end{array}$ \\
\hline $\begin{array}{l}\text { My family (partner/ parents) are } \\
\text { very supportive in balancing my } \\
\text { work life }\end{array}$ & $\begin{array}{l}14 \\
(9.33 \%)\end{array}$ & $\begin{array}{l}11 \\
(7.33 \%)\end{array}$ & $\begin{array}{l}25 \\
(16.66 \%)\end{array}$ & $\begin{array}{l}53 \\
(35.33 \%)\end{array}$ & $\begin{array}{l}47 \\
(31.33 \%)\end{array}$ & $\begin{array}{l}150 \\
(100 \%)\end{array}$ \\
\hline \multicolumn{7}{|c|}{ Effects of Work Obstructions on Family } \\
\hline $\begin{array}{l}\text { Due to my job, I regularly face } \\
\text { problems in my family }\end{array}$ & $\begin{array}{l}15 \\
(10 \%)\end{array}$ & $\begin{array}{l}27 \\
(18 \%)\end{array}$ & $\begin{array}{l}38 \\
(25.33 \%)\end{array}$ & $\begin{array}{l}47 \\
(31.33 \%)\end{array}$ & $\begin{array}{l}23 \\
(15.33 \%)\end{array}$ & $\begin{array}{l}150 \\
(100 \%)\end{array}$ \\
\hline $\begin{array}{l}\text { My company is very supportive in } \\
\text { balancing my personal \& } \\
\text { professional life too }\end{array}$ & $\begin{array}{l}27 \\
(18 \%)\end{array}$ & $\begin{array}{l}58 \\
(38.66 \%)\end{array}$ & $\begin{array}{l}30 \\
(20 \%)\end{array}$ & $\begin{array}{l}23 \\
(15.33 \%)\end{array}$ & $\begin{array}{l}12 \\
(8 \%)\end{array}$ & $\begin{array}{l}150 \\
(100 \%)\end{array}$ \\
\hline
\end{tabular}

DOI: $10.9790 / 487 X-1905053538$

www.iosrjournals.org

$36 \mid$ Page 
From the above table number- 3 it can be seen how work $\&$ family creates problems $\&$ how they are considered as a difficult task to balance the both personal \& professional life. The below mentioned statements regarding the effects of family obstructions on work explaining about-

- "In doing my job my family life got more interrupted", where $12.66 \%$ (some what agree) $+40.02 \%$ (Agree) $+33.33 \%$ (strongly agree) which is in total $-86.01 \%$ of women employee's family got disturbed due to their professional work where as only $7.33 \%$ (Strongly disagree) $+6.66 \%$ (Disagree) which is total $-13.98 \%$ of women employees are not having this issue of getting disturbed by their work.

- In the statement "My family (partner/ parents) are very supportive in balancing my work life" , the findings reveals that $16.66 \%$ ( somewhat agree) $+35.33 \%$ (Agree) $+31.33 \%$ (strongly agree) which shows that $83.32 \%$ of female employees are getting full support from their family members, whereas only $9.33 \%$ (strongly disagree) $+7.33 \%$ ( disagree) which means total $16.66 \%$ of total females are facing problems in terms of support from their family members.

When researcher tried to analyze the effect of work obstruction on family the findings were like this-

- "Due to my job, I regularly face problems in my family", in answer to this question 10\% (strongly disagree) $+18 \%$ (disagree) in total disagreement is $28 \%$ of female are denying about the problems in family due to their jobs but parallel major section of female employee's is agreeing to this which is like $25.33 \%$ (somewhat agree) $+31.33 \%$ (agree) $+15.33 \%$ (strongly agree) in total agreement $-71.99 \%$ of female facing problems in their family because of their work.

- The statement like "My company is very supportive in balancing my personal \& professional life too", the respondents were $18 \%$ (strongly disagree) $+38.66 \%$ (disagree) which shows total disagreement $-56.66 \%$ whereas $20 \%$ (somewhat agree) $+15.33 \%$ (agree) $+8 \%$ (strongly agree) which shows total agreement $43.33 \%$. it may be because of changes in policies of employers.

\section{Major Findings}

1. As per the opinion around $93.32 \%$ of female employees believes that their work \& their family obstruct each other \& which may be because of the challenging demands of the today's environment.

2. Around $36.66 \%$ of females saying that they are able to meet the demands \& needs of their work \& family both which could be because they might be in a profession where they will be getting their space $\&$ time to manage it but, major percentage of females are denying this.

3. $82.76 \%$ of female employees enjoy less at their work place due to the undue pressures of their work place. These pressures are making them more depressive in coping with the advancements in every field.

4. $84.65 \%$ of female employees wish to change their current job if they will get the new job through which they can more balance their work \& family life.

5. As per the evaluation of effects of family on work, $86.01 \%$ of female believes that their family is affected more due to their job but, surprisingly $83.32 \%$ of female employees are getting full support from their parents \& partners to be in job. This finding is enough motivating to understand about the women empowerment from the family side.

6. Similarly, when effects of work obstruction seen on family the findings were like around $71.99 \%$ of female employees are compromising with their family obligations due to their job \& $56.66 \%$ of female employees are saying that their employers are not supportive in managing their work \& their family life.

\section{Suggestion}

1. Females should be given more opportunities or plate forms where they can explore their strength to better utilize at their workplace which further may result in effective balance with the changing environment.

2. They should be allowed to work in official hours only. Employer should not impose double time work or extra work load on them.

3. Facilities like crèches, transportation should be maintained by employer on large scale if the female number of employees is there.

4. Females should also be given more option for working from home facilities so that on urgent basis they are at home \& at their job also.

5. If females are working then employer should also provide residential facilities to them as per their status of marriage \& family or if they do not belongs to the local area. It would be helping them in doing their jobs tension free.

\section{Conclusion}

As per the findings of the study females are really doing tough work to manage their family \& their work responsibilities. There is lot of support from family is given to them to work effectively but at the same time most of the organization are found not to be cooperative \& supportive to them. This is difficult for them to manage at both the side. Female are coming out of their family limitations but we are not supporting them, there 
is lack of understanding. Female can be more fruitful \& effective as the employees if policy implementation should be done on regular basis which will help them to manage more family \& work life in a better way. In Gwalior there is a scenario due to which female prefer more jobs in teaching area as it is considered as the safest job for them. But, teaching or academic institutions do not have full fledge policies in regards to crèches, transportation etc. The employer should consider it as it is important to give support \& as well as it is important for the growth of state \& country also.

\section{References}

[1] Ashtankar, O. M. (2016). Analysis of the impact of work life balance on wellbeing of police department employees of Nagpur district. IJAR, 2(5), 380-383.

[2] Chowdhury, M. M., Hoque, N., \& Mohammed Jonayed Kabir, M. (2015). Work-Life Balance of Female Garment Workers in Bangladesh: An Imperial Investigation. Global Journal of Management And Business Research, 15(7).

[3] Crosbie, T., \& Moore, J. (2004). Work-life balance and working from home. Social Policy and Society, 3(03), 223-233.

[4] Deivasigamani, J., \& Shankar, G. (2014). A study on worklife balance of employees in information techonolgy (it) sector at chennai. International Journal of Management Research and Reviews, 4(8), 805.

[5] Delina, G., \& Raya, R. P. (2013). A study on work-life balance in working women. Women, 2(5).

[6] Francis, R. S., \& Sangaran, M. G. A conceptual paper on work family balance in the hotel industry: a malaysian perspective.

[7] Kim, H. K. (2014). Work-Life Balance and Employees' Performance: The Mediating Role of Affective Commitment. Global Business and Management Research, 6(1), 37.

[8] Lazar, I., Osoian, C., \& Ratiu, P. (2010). The role of work-life balance practices in order to improve organizational performance. European Research Studies, 13(1), 201.

[9] Manisha, P. (2013). A comparative study of work life balance in various industrial sectors in Pune region. International Journal of Marketing, Financial Services and Management Research, 2(3), 198-206.

[10] Oludayo, O. O., Gberevbie, D. E., Popoola, D., \& Omonijo, D. O. (2015). A study of multiple work-life balance initiatives in banking industry in Nigeria. A Study of Multiple Work-life Balance Initiatives in Banking Industry in Nigeria, (133), 108-125.

[11] Rani, S. V., \& Selvarani, M. (2010). Work/life balance reflections on employee satisfaction.

[12] Shukla, S., \& Bagali, P. M. (2016). A Study on Work Life Balance: In Indian Travel and Tourism Industry. International Journal of Research in IT, Management and Engineering, 6 (3), 21.

[13] Soni, H., \& Rawal, Y. S. (2014). Impact of quality of work life on employee satisfaction in hotel industry. IOSR Journal of Business and Management, 16(3), 37-44.

[14] Susi, S., \& Jawaharrani, K. (2011). Work-Life Balance: The key driver of employee engagement. Asian journal of management research, 2(1), 474-483. 